\title{
Effects of strength training on health determinants in men over 65 years: a systematic review
}

\author{
Juan Valiente-Poveda, Daniel Castillo, Javier Raya-González \\ Facultad de Ciencias de la Salud. Universidad Isabel I. Burgos.
}

doi: $10.18176 /$ archmeddeporte.00054

Received: 18/09/2020

Accepted: 21/05/2021

Key words: Adult. Physical activity. Health. Resistance training.

Palabras clave: Adulto. Actividad física. Salud. Entrenamiento con cargas.

\section{Summary}

Introduction: Aging is associated with a reduction in physical activity levels, leading to a decrease in strength and muscle mass, and affecting the minimum functional capacity to maintain an independent life. The literature agrees that strength training is one of the most important strategies to curb the effects of age, since it has been shown to be effective in increasing muscle mass and strength, promoting improvements in the functional capacity of the elderly. Therefore, the aim of this study was to analyze the effects of strength training on the conditioning factors of health and quality of life (e.g., body composition, muscle strength and functional capacity) in male adults over 65 years of age.

Material and method: A data search were conducted in PubMed, SPORTdiscus and Web Of Science (WOS) databases according to the recommendations and criteria established in the Preferred Reporting Items for Systematic Reviews and Meta-analysis (PRISMA) statement guidelines. For this, the search terms related to the target population (male older adults) and the type of training applied (strength training) were used.

Results: After applying the search strategies, a total of 2196 articles were obtained. After reading the title and abstract, 1687 articles were eliminated. After reading the full text, 151 articles were eliminated and 9 were selected, which met the inclusion criteria and were therefore included in this review.

Conclusions: The results suggest the importance of focus the strength training programs to the individual demands of each older adult man, in order to optimize its effects, and ultimately, improve their quality of life.

\section{Efectos del entrenamiento de fuerza sobre las capacidades determinantes de la salud en hombres mayores de 65 años: una revisión sistemática}

\section{Resumen}

Introducción: El envejecimiento lleva asociado una reducción de los niveles de actividad física, propiciando la disminución de la fuerza y masa muscular, y afectando a la capacidad funcional mínima para mantener una vida independiente. La literatura coincide en que el entrenamiento de fuerza es una de las estrategias más importante para frenar los efectos de la edad, dado que se ha demostrado que es efectiva para incrementar la masa muscular y la fuerza, propiciando mejoras en la capacidad funcional del adulto mayor. Por ello, el objetivo del presente estudio fue analizar los efectos del entrenamiento de fuerza sobre los factores condicionantes de la salud y calidad de vida (p.e., composición corporal, fuerza muscular y capacidad funcional) en adultos masculinos mayores de 65 años.

Material y método: Se realizó una búsqueda bibliográfica en las bases de datos PubMed SPORTdiscus, y Web Of Science (WOS) de acuerdo con las líneas de recomendación para revisiones sistemáticas y meta-análisis PRISMA. Para ello, se utilizaron los términos de búsqueda relacionados con la población objetivo (adultos mayores masculinos) y el tipo de entrenamiento aplicado (entrenamiento de fuerza).

Resultados: Tras aplicar las estrategias de búsqueda, se obtuvieron un total de 2196 artículos. Tras la lectura de título y resumen se eliminaron 1687 artículos. Tras la revisión de los textos completos, se eliminaron 151 artículos y se seleccionaron 9, los cuales cumplieron los criterios de inclusión, por lo que fueron incluidos en esta revisión sistemática.

Conclusiones: Los resultados sugieren la importancia de orientar el entrenamiento de fuerza seleccionando el tipo de carga (moderada, alta o combinada) más adecuada para conseguir los objetivos individuales de cada hombre adulto mayor con la intención de optimizar sus niveles de composición corporal, capacidad funcional, masa muscular y fuerza máxima, para consecuentemente, mejorar su calidad de vida. 


\section{Introduction}

The demographic evolution in developed countries reflects an ageing population, due to rising life expectancy and the fall in birth rates $^{1,2}$. According to the National Statistics Institute (INE), life expectancy was 80.43 years for men and 85.80 for women in 2018, with a rising trend in subsequent years. This leads to an ageing population, to the point that currently $19.2 \%$ of the Spanish population is aged over 65 years old and in 2033, this will reach 25.2\% (INE, 2018). In this respect, ageing is a major problem, not only because of its socio-economic repercussions, but also due to the changes that occur in the subjects, usually associated with a drop in their quality of life?

In this respect, it has been demonstrated that ageing brings a physiological decline mainly seen in impairment of neuromuscular, cardiovascular and pulmonary systems ${ }^{3-5}$. However, it is the degeneration of the muscular system caused by the progressive loss of strength and muscle mass which limits the functional capacity and independence of older adults ${ }^{6,7}$, increasing the risk of suffering disease and even death ${ }^{8}$. This loss of muscle mass, strength and functioning of muscles in older adults is commonly known as sarcopenia?.

Given that a certain level of strength is required to carry out any daily activity, as they lose functionality, older adults must increase their physical effort for the same activity, which implies working at a relatively higher intensity in terms of their maximum capacity ${ }^{10}$, thereby making the same task more tiring ${ }^{11}$. This physiological challenge means that older adults reduce their physical activity ${ }^{12}$ and, like a self-perpetuating cycle, as physical activity is reduced, they lose strength and muscle mass $^{13}$. On the other hand, with the increase in inactivity as a consequence of muscular weakness, there is a loss of mobility and functional capacity ${ }^{14}$, which will negatively affect the risk of falls, generating greater deterioration among older adults ${ }^{15}$.

There is robust scientific evidence to uphold the theory that physical exercise could reverse this situation ${ }^{12,16-19}$. Specifically, in the last few decades, strength training has been consolidated as the main strategy to reduce strength and muscle mass deficits in older adults ${ }^{20}$. In this respect, a large number of prior studies have applied different strength training programmes to older adult males, basically differentiated by the load used, although with similar results regarding the gain in muscular strength. For example, Radaelli et al. ${ }^{21}$ applied a strength programme based on moderate loads [(50-65\% of a maximum repetition (1MR)] and they observed significant strength gains in the $1 \mathrm{MR}$ test in the knee extension exercise $(P<0.05)$ and increases in the thickness and muscular quality of quadriceps $(P<0.05)$. On the other hand, Mitchel et al. ${ }^{22}$ used high loads (85\% 1MR) and obtained significant increases $(P<0.05)$ in the $1 M R$ test for the leg press, knee extension and bench press after the intervention period. Other authors applied strength protocols based on combining moderate and high loads (from 65\% to $95 \%$ of $1 M R)$, demonstrating significant results $(p<0.05)$ in the increase of lean mass, in the reduction of fat mass and improvements in lower and upper body strength ${ }^{23}$.
However, although strength training was demonstrated to have a positive effect on improving muscular function in older adults, there is no current evidence of consensus on what type of training and strength is the most appropriate and which generates the most beneficial effects as different results can be obtained depending on the loads used. Therefore, the main aim of this review was to analyse the effects of strength training on health determinants in older adult males, focusing on the loads used [i.e., moderate (50-80\% 1MR), high (> 80\% 1MR) or combined].

\section{Material and method}

To carry out this systematic review, the recommendations from the PRISMA ${ }^{24}$ declaration were followed. The scientific literature was reviewed to analyse the effects of strength training on health determinants in older people ( $>65$ years old). To do this, original experimental scientific articles were consulted, in English and Spanish, with a time filter from 1 January 2014 to 15 February 2019. The databases consulted were Pubmed, SPORTdiscus, and Web of Science (WOS).

The search strategy resulted from combining the following descriptors: "elderly"and "older adult" (target population); "strength training," "resistance training", "power training,", "heavy resistance training," "moderate resistance training," "low resistance training”, "maximal strength training”, "velocity-based training," "circuit-based training", "high speed resistance training," "resistance exercise,", "velocity-based resistance training”,"circuit training," "high-velocity resistance training", "concurrent training", "multicomponent training".

The final search was carried out using the following combination of terms: (elderly OR "older adult") AND ("strength training" OR "resistance training" $O R$ "power training" $O R$ "heavy resistance training" $O R$ "moderate resistance training" OR "low resistance training" OR "maximal strength training"OR"velocity-based training" OR "circuit-based training" OR"high speed resistance training" OR "resistance exercise" OR "velocity-based resistance training" OR "circuit training" OR "High-velocity resistance training" $O R$ "concurrent training" OR "multicomponent training")

The inclusion criteria were: (a) use healthy men over 65 years old as a study sample, (b) apply a strength training programme evaluated by a pre-post test, (c) present the intensity of the programme indicated as a percentage of $1 \mathrm{MR}$ and (d) articles published in well-respected international journals, indexed in the Web of Science, while the exclusion criteria were: (a) studies that were not experimental, (b) application of the training programmes was not directly supervised, (c) intervention programmes where strength training was combined with training on other aspects, (d) strength training programmes combined with nutritional intervention and (e) interventions that lasted under 6 weeks. The search process was carried out independently by 2 authors (J.V.-P. and J.R.-G.) and in cases of discrepancies, a third author (D.C.) was consulted.

\section{Results}

The preliminary search found 2196 articles. The articles were filtered by firstly eliminating the duplicate references extracted from the 
various databases, giving a total of 1847 articles. Subsequently, these articles were filtered by reading the title and abstract, leaving a total of 160 references. Finally, the selected articles were read in their entirety, applying the inclusion and exclusion criteria to obtain a total of 9 articles for the systematic review (Figure 1).

The sample size of the 9 selected studies was 128 participants, only including experimental subjects. The age range for the participants was between 50 and 80 years old. Analysis of the training protocols identified that the most frequently-used duration was 12 weeks (55\%). Regarding the weekly training frequency, it was seen that 3 days a week was the most popular frequency (77\%), followed by 2 days a week (44\%). Regarding the load used, 2 studies used moderate loads, 3 used high loads and 5 combined loads. The studies included in the review, and their main characteristics, are presented in Table 1.

\section{Discussion}

The aim of this review was to analyse the effects of strength training on health determinants in older adult males, examining the loads used (i.e., moderate, high or combined).

\section{Figure 1. Flow diagram to describe the systematic review proce-} dure.

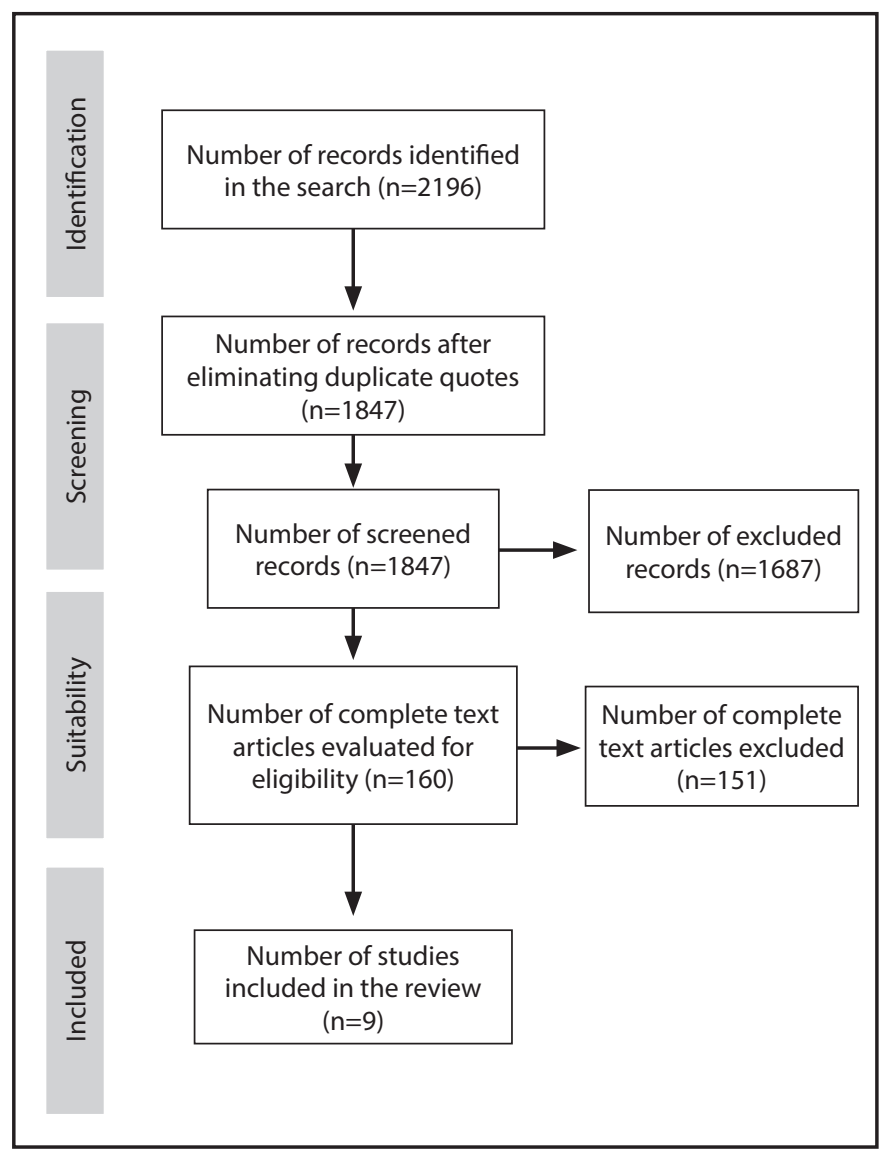

Focusing on the effects caused by strength training with moderate loads, Sundstrup et al. ${ }^{25}$ applied a training programme over 12 weeks that consisted of a circuit of strength exercises involving the main muscles in the upper and lower body. The intensity ranged between 70 and $80 \% 1 \mathrm{MR}$, performing 3-4 sets of each exercise, with repetitions ranging between 8 and 12. After the intervention period, the older adults obtained significant improvements in concentric strength $(14 \% ; p<0.01)$ and isometric strength in quadriceps (23\%; $<<0.001)$, and in isometric strength of hamstring musculature (44\%, $p<0.0001)$, measured using an isokinetic dynamometer. Furthermore, 18\% improvements were seen in the stair-climbing test $(p<0.05)$ and $21 \%$ in the sit-to-stand test $(p<0.05)$. Continuing with the moderate loads, Zdzieblik et al. ${ }^{26}$ carried out a strength training programme with an intensity of $65-80 \%$ $1 \mathrm{MR}$ for 12 weeks. The older adults carried out this programme with a frequency of 3 days a week, composed of 4 exercises, 2 for the lower body (leg press and squats) and 2 for the upper body (bench press and lat pulldowns). Regarding the training volume, 3 sets of 15 repetitions were done in weeks 1-4, 10 repetitions in weeks 5-9 and 8 repetitions in weeks 10-12. The results showed an increase in lean mass and bone mass, and a reduction in fat mass. Furthermore, this strength programme with moderate loads allowed older adults to increase their muscular strength and improve their neuromuscular control.

Regarding the use of high loads with older adults, Baptista et al. ${ }^{27}$ analysed the effect of a strength programme with $80 \% 5 \mathrm{MR}$ loads on the neuromuscular and structural properties of the muscle-tendon complex of quadriceps in 23 older adults. This programme lasted 12 weeks, it was performed with a frequency of 2 days per week and was based on a single exercise, concentric or eccentric knee extension. After the intervention period, it was observed that both protocols increased the maximum force of the knee extensor musculature and reduced the length of the vastus lateralis fascicle and increased its pennation angle. In the same way, significant increases were found in the length of the patellar tendon in both groups, while an increase in the anatomical cross section of the tendon only increased significantly in eccentric training. These anatomical variations after inclusion of the aforementioned strength training programme seem to affect the dynamic balance of older adults. Finally, after the intervention period, both groups increased the isometric and dynamic torque of the eccentric and concentric strength of the knee. Along this line, Beurskens et al. ${ }^{28}$ studied the effects of a training programme with loads of $80 \% 1 \mathrm{MR}$ over the maximum production of unilateral and bilateral isometric strength (IMS) and over the bilateral limb deficit. The intervention took place with 58 men over 13 weeks and with a frequency of 3 days a week and they carried out 3 sets of 10 repetitions of the leg press, knee extension, ankle extension and foot dorsiflexion exercises. After applying this training programme, an increase was observed in maximum isometric strength, both bilateral and unilateral, and a reduction in the participants' bilateral limb deficit. Finally, Mitchell et al. ${ }^{22}$ analysed the effects of the strength training with high loads over the strength and hypertrophy level in 16 older 
Table 1. Strength training programmes applied using older adult males.

\begin{tabular}{|c|c|c|c|c|}
\hline Study & Sample & Loads used & Training protocol & Results \\
\hline Zdzieblik et al. (2015) & $\begin{array}{l}27 \text { men } \\
(72.2 \pm 4.68 \\
\text { years old })\end{array}$ & Moderate & $\begin{array}{l}12 \text { weeks } 3 \mathrm{~d} / \text { week } \\
65-80 \% 1 \mathrm{MR} \text {. } \\
\text { Lat pulldown, leg press; bench press; reverse } \\
\text { squat. }\end{array}$ & $\begin{array}{l}\uparrow L M, \uparrow B M, \uparrow F M \text { and } \downarrow F M(p<0.001) \text { and } \\
\uparrow I Q S \text { and } \uparrow S M C ;(p<0.01) .\end{array}$ \\
\hline $\begin{array}{l}\text { Sundstrup et al. } \\
\text { (2016) }\end{array}$ & $\begin{array}{l}9 \text { men } \\
(68.2 \pm 3.2 \text { years } \\
\text { old })\end{array}$ & Moderate & $\begin{array}{l}\text { Month 1: [16-20 rep. }(50-60 \% \text { MR)]. Months 2-12: } \\
\text { [8-12 rep. ( } 70-80 \% \text { MR)]. } \\
\text { 3-4 sets } 3 \text { days a week } \\
\text { Recovery: } 1 \text { min } 30 \text { s } \\
\text { Leg press, seated knee extension, lying } \\
\text { hamstring curl; lat pulldown, lateral raises, lunges } \\
\text { with hand weights, seated row. }\end{array}$ & 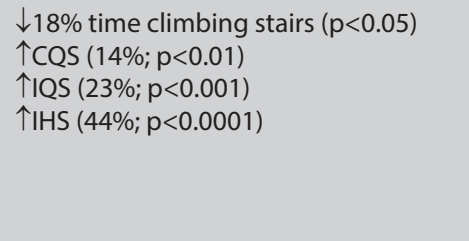 \\
\hline Beurskens et al. (2015) & $\begin{array}{l}19 \text { men } \\
\text { (60-80 years old) }\end{array}$ & High & $\begin{array}{l}13 \text { weeks } 3 \mathrm{~d} / \text { week } \\
3 \text { sets } \times 10 \text { rep. ( } 80 \% 1 \mathrm{MR}) \text {. Recovery: } 2^{\prime} \text {. } \\
\text { Leg press; knee extension; ankle extension; foot } \\
\text { dorsiflexion. }\end{array}$ & $\begin{array}{l}\text { Left leg IMS: } \uparrow 10 \%, p<0.001, d=2.3 \text {. } \\
\text { Right leg IMS: } \uparrow 8 \% p<0.05, d=1.8 \text {. } \\
\text { Bilateral IMS: } \uparrow 26 \%, p<0.001, d=5.7 \text {. } \\
\text { BLD: } \downarrow 78 \%, p<0.001, d=3.4 \text {. }\end{array}$ \\
\hline Mitchell et al. (2015) & $\begin{array}{l}16 \text { men } \\
(74 \pm 5.4 \text { years } \\
\text { old) }\end{array}$ & High & $\begin{array}{l}12 \text { weeks, } 3 \text { days/week; } 4 \text { sets } 85 \% 1 \mathrm{MR} \text {. } \\
\text { Leg press, leg extension; hamstring curl; } 45^{\circ} \\
\text { ankle extension; bench press; lat pulldown; } \\
\text { shoulder press; seated row; biceps curl; elbow } \\
\text { push downs. }\end{array}$ & $\begin{array}{l}\uparrow 1 M R \text { in leg press, knee extension, } \\
\text { bench press }(p<0.05) \\
\uparrow \text { Type I fibres }(p<0.008)\end{array}$ \\
\hline Baptista et al. (2016) & $\begin{array}{l}23 \text { men }(62.74 \pm \\
2.20 \text { years old })\end{array}$ & High & $\begin{array}{l}12 \text { weeks } 2 \mathrm{~d} / \text { week } \\
80 \% 5 \mathrm{MR} \text { ( } 4 \text { rep.). } \\
\text { Concentric group and eccentric group }\end{array}$ & $\begin{array}{l}\text { Both groups } \uparrow \text { Knee extension } \\
\text { strength } \\
\text { Both groups } \uparrow \text { patellar tendon length, } \\
\text { but patellar tendon CSA only in ECC, } \\
\text { ( } p<0.05 \text { ). } \\
\text { Both groups } \downarrow \text { VL fascicle length and } \\
\uparrow \text { pennation angle with no change in } \\
\text { muscular thickness. } \\
\text { Both groups } \uparrow \text { isometric and } \\
\text { dynamic torque of the knee extensor } \\
\text { musculature. }\end{array}$ \\
\hline Andersen et al. (2014) & $\begin{array}{l}9 \text { men } \\
(68.2 \pm 3.2 \text { years } \\
\text { old })\end{array}$ & Combined & $\begin{array}{l}16 \text { weeks } 2 \text { d/week } \\
\text { Weeks 1-4: } 3 \text { sets } \times 16-20 \text { MR (50-60\%) } \\
\text { Weeks 5-8: } 3 \text { sets } \text { x } 12 \text { MR (70\%). } \\
\text { Weeks 9-12: } 3 \text { sets } \times 10 \text { MR (75\%). } \\
\text { Weeks 12-16: } 4 \text { sets } \times 8 \text { MR ( } 80 \%) \text {. } \\
\text { Leg press, seated knee extension, hamstring curl; } \\
\text { lat pulldown, lateral raises with hand weights }\end{array}$ & $\begin{array}{l}\downarrow \text { Walking HR, }(p<0.05) \downarrow 10 \% \text {; } \\
\text { Running HR and [La]: } 30 \%(p<0.001) \text {. } \\
\uparrow \text { STS: } \uparrow 26 \%\end{array}$ \\
\hline Schmidt et al. (2014) & $\begin{array}{l}9 \text { men } \\
(68.2 \pm 3.2 \text { years } \\
\text { old })\end{array}$ & Combined & $\begin{array}{l}12 \text { months } \\
\text { Month 1-4: } 2 \mathrm{~d} / \text { week } 3 \text { sets. Recovery: } 90^{\prime \prime} \\
\text { Month 5-12: } 3 \mathrm{~d} / \text { week } 4 \text { sets. Recovery: } 90^{\prime \prime} \\
\text { Month 1: } 16-20 \text { MR ( } 50-60 \% 1 \mathrm{MR}) \\
\text { Month 2: } 12 \mathrm{MR}(67 \% 1 \mathrm{MR}) \\
\text { Month 3: } 10 \mathrm{MR}(75 \% 1 \mathrm{MR}) \\
\text { Month } 4 \text { to 12: } 8 \text { MR ( } 80 \% 1 \mathrm{MR}) \text {. } \\
\text { Leg press, seated knee extension, hamstring curl; } \\
\text { lat pulldown, lateral raises with hand weights. }\end{array}$ & $\begin{array}{l}\uparrow 5 \%(p<0.05) L V \text { ejection fraction, with } \\
\text { no significant changes in the diastolic } \\
\text { function of the LV. }\end{array}$ \\
\hline $\begin{array}{l}\text { Villanueva et al. } \\
\text { (2014) }\end{array}$ & $\begin{array}{l}7 \text { men } \\
(68.1 \pm 6.1 \text { years } \\
\text { old })\end{array}$ & Combined & $\begin{array}{l}12 \text { weeks } 3 \mathrm{~d} / \text { week } 2-6 \text { set } \\
\text { Day 1: } 12-8 \mathrm{MR} .67-80 \% \\
\text { Day 2: 6-3 MR. } 85-93 \% \\
\text { Day 3: } 6-4 \text { MR. } 70 \% \text { power } \\
45^{\circ} \text { leg press, bench press on a machine, lat } \\
\text { pulldowns, seated row, stair climbing with hand } \\
\text { weights, dead lift with hand weights and knee } \\
\text { extension and flexing. }\end{array}$ & $\begin{array}{l}\uparrow L M(\text { week } 6)(p<0.05) . \\
\downarrow F M(p=0.05) \\
\downarrow \% C O(\text { week 12) }(p=0.05) . \\
\uparrow \mathrm{VO}_{2 \max }(\text { week } 6 \text { and week 12) }(p<0.01)\end{array}$ \\
\hline
\end{tabular}




\begin{tabular}{|c|c|c|c|c|}
\hline Study & Sample & Loads used & Training protocol & Results \\
\hline $\begin{array}{l}\text { Fernández-Lezaun } \\
\text { et al. (2017) }\end{array}$ & $\begin{array}{l}29 \text { men } \\
(69 \pm 3 \text { years } \\
\text { old })\end{array}$ & Combined & 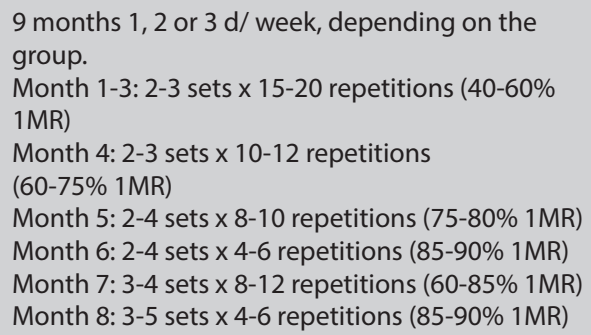 & $\begin{array}{l}\text { Month 1-3: All groups } \uparrow \mathrm{VO} 2(\mathrm{p}<0.05) \text {. } \\
\text { Months 4-9: no significant improve- } \\
\text { ments. } \\
\uparrow 1 \mathrm{MR} \text { months } 1-3 \text { all groups except M2 } \\
\text { and months } 4-9 \text { only in M3. }\end{array}$ \\
\hline
\end{tabular}

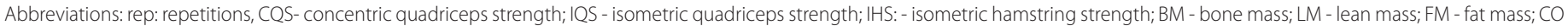

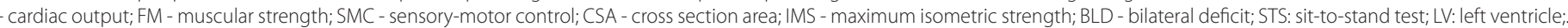

adults. To do this, they designed a strength training programme based on bench press, leg press, lat pulldown, knee extension, military press, hamstring curl and bicep curl exercises. This programme was performed for 12 weeks and 3 days a week, with a training load of 4 sets at $85 \%$ of $1 \mathrm{MR}$. After application, improvements were seen in the $1 \mathrm{MR}$ for leg press, knee extension, and an increase in the percentage of type I fibres although not type II fibres.

Regarding studies that applied programmes based on combined loads, Andersen et al..$^{29}$ analysed the effect of a 16-week multi-exercise intervention with a frequency of 3 times a week. The functional capacity performance and the physiological response to the test to walk at 4.5 $\mathrm{km} \cdot \mathrm{h}^{-1}$, the submaximal running test and the maximum incremental on the stationary bike (maximum oxygen consumption, lactate, time to exhaustion). The load applied progressed from the 3 sets of 16-20 repetitions at 50-60\% $1 \mathrm{MR}$, in the first 4 weeks, to 4 sets at $80 \%$ in weeks 12-16. At the end of the intervention period, the older adults reduced their heart rate walking and running, as well as demonstrating a lower concentration in lactate peak in the running test. Furthermore, 26\% improvements were seen in the sit-to-stand test. The second study that applied combined loads was run by Fernández-Lezaun et al. ${ }^{30}$, who analysed the effects of the frequency of a strength programme on the cardio-respiratory capacity and strength values. The study took place over 9 months with a different weekly frequency depending on the group (1, 2 or 3 sessions). The training load ranged from 4-6 repetitions to $15-20$, sets between 2-5 and intensity from 30 to $90 \%$ of $1 \mathrm{MR}$. After the intervention, it was seen that during months 1-3, all the groups improved their maximum oxygen consumption, although during months 4-9, improvements were not seen in any of the tests performed. Finally, during months 1-3, all groups improved 1 MR for the leg press except for the group that did 2 weekly sessions and during months 4-9, only the 3 weekly session group improved. Subsequently, Schmidt et al. ${ }^{31}$ studied the effects of a strength programme with combined loads lasting 12 months on cardiovascular adaptations in older adult males. The intensity of the programme varied from 40\% 1MR up to 90\% of 1MR, applied in the leg press, knee extension, hamstring curl, lat pulldown and side raises with hand weight exercises. After the intervention, a 5\% increase was seen in the left ventricular ejection fraction with no significant changes in the rest of the markers analysed. Finally, Villanueva et al. ${ }^{23}$ analysed the effects of a combined load strength programme applied over 12 weeks with a frequency of 3 days a week, varying the training load on each of those days. In this respect, on day 1, they did 8-12 repetitions at $67-80 \% 1 \mathrm{MR}$; on day 2, 3-6 repetitions at $85-93 \%$ and on day 3, they did 4 to 6 repetitions at 70\% $1 \mathrm{MR}$. The exercises used in this programme were $45^{\circ}$ leg press, bench press on a machine, lat pulldowns, seated row, stair climbing with hand weights, dead lift with hand weights and knee extension and flexing. After applying the strength programme, an increase in the lean mass was seen and a reduction in the fat mass. Furthermore, cardiac output was reduced, and maximum oxygen consumption increased.

\section{Conclusion}

In general, during the first phases of the training, and mainly in outof-practice adults, strength training seemed to be a safe and effective strategy to improve body composition, muscular strength and the functional capacity of older adult males. Specifically, moderate loads seem to be appropriate to improve the body composition, functional capacity and isometric strength, possibly because these loads were located in the zone of maximum power production on the strength-speed curve. On the other hand, high loads seem to have greater influence on strength and muscle mass, a fundamental aspect to prevent and treat sarcopenia. Finally, the strength training with combined loads seems to improve the functional and cardiovascular capacity of older adults, and their body composition. The results of this systematic review suggest the importance of guiding strength training towards individual goals for each older adult male, to optimise its effects and in short, improve their quality of life.

\section{Thanks}

The authors would like to thank the following subproject for its support: Enfoque de método mixto en el análisis de rendimiento (en 
entrenamiento y competición) en el deporte de élite y academia [Mixedmethod focus on performance analysis (in training and in competition) in elite and academy sport] [PGC2018-098742-B-C33] (2019-2021) [from the Ministry of Science, Innovation and Universities (MCIU), the State Research Agency (AEI) and the European Regional Development Fund (ERDF)], that form part of the coordinated project: New approach of research in physical activity and sport from mixed methods perspective (NARPAS_MM) [SPGC201800X098742CV0].

\section{Conflict of interests}

The authors do not declare any conflict of interests.

\section{Bibliography}

1. Porcel MA, Valpuesta ER. Ageing in Spain: It's a challenge or social problem? Gerokomos. 2012;23:151-5

2. Guijarro M, Peláez Ó. La longevidad globalizada: un análisis de la esperanza de vida en España (1900-2050). Scr Nova Rev Electrónica Geogry Ciencias Soc. 2008;12:256-80.

3. Frontera WR, Hughes VA, Lutz KJ, Evans WJ. A cross-sectional study of muscle strength and mass in 45- to 78-yr-old men and women. J Appl Physiol. 1991;71:644-50.

4. Häkkinen K, Kallinen M, Izquierdo M, Jokelainen K, Lassila H, Mälkiä E, et al. Changes in agonist-antagonist EMG, muscle CSA, and force during strength training in middleaged and older people. J Appl Physiol. 1998;84:1341-9.

5. Izquierdo M, Ibañez J, Gorostiaga E, Garrues M, Zûñiga A, Antón A, et al. Maximal strength and power characteristics in isometric and dynamic actions of the upper and lower extremities in middle-aged and older men. Acta Physio/ Scand. 1999;167:57-68.

6. Aagaard P, Suetta C, Caserotti P, Magnusson SP, Kjær M. Role of the nervous system in sarcopenia and muscle atrophy with aging: Strength training as a countermeasure. Scand J Med Sci Sports. 2010;20:49-64.

7. Larsson L, Degens H, Li M, Salviati L, Lee Y II, Thompson W, et al. Sarcopenia: Agingrelated loss of muscle mass and function. Physiol Rev. 2019;99:427-511.

8. Mesquita AF, da Silva EC, Eickemberg M, Roriz AKC, Barreto-Medeiros JM, Ramos LB. Factores asociados con la presencia de sarcopenia en ancianos institucionalizados. Nutr Hosp. 2017;34:345-51.

9. Cruz-Jentoft AJ, Baeyens JP, Bauer JM, Boirie Y, Cederholm T, Landi F, et al. Sarcopenia: European consensus on definition and diagnosis. Age Ageing. 2010;39:412-23.

10. Hortobágyi T, Mizelle C, Beam S, DeVita P. Old adults perform activities of daily living near their maximal capabilities. Journals Gerontol - Ser A Biol Sci Med Sci. 2003;58:453-60.

11. Seguin $R$, Nelson ME. The benefits of strength training for older adults. Am J Prev Med. 2003;25:141-9.

12. Taylor D. Physical activity is medicine for older adults. Postgrad Med J. 2014;90:26-32.

13. Hunter GR, McCarthy JP, Bamman MM. Effects of resistance training on older adults. Sports Med. 2004;34:329-48

14. Volaklis KA, Halle M, Meisinger C. Muscular strength as a strong predictor of mortality: A narrative review. Eur J Intern Med. 2015;26:303-10.
15. Hindmarsh JJ, Estes EH. Falls in Older Persons: Causes and interventions. Arch Intern Med. 1989;149:2217-22.

16. Hupin D, Roche F, Gremeaux V, Chatard JC, Oriol M, Gaspoz JM, et al. Even a low-dose of moderate-to-vigorous physical activity reduces mortality by $22 \%$ in adults aged z60 years: A systematic review and meta-analysis. Br J Sports Med. 2015;49:1262-7.

17. Landi F, Marzetti E, Martone AM, Bernabei R, Onder G. Exercise as a remedy for sarcopenia. Curr Opin Clin Nutr Metab Care. 2014;17:25-31.

18. Marzetti E, Calvani R, Tosato M, Cesari M, Di Bari M, Cherubini A, et al. Physical activity and exercise as countermeasures to physical frailty and sarcopenia. Aging Clin Exp Res. 2017;29:35-42.

19. Nelson ME, RejeskiWJ, Blair SN, Duncan PW, Judge JO, King AC, et al. Physical activity and public health in older adults: Recommendation from the american college of sports medicine and the american heart association Med Sci Sports Exerc. 2007;39:1435-45.

20. Casas Herrero Á, Cadore EL, Martínez Velilla N, Izquierdo Redin M. El ejercicio físico en el anciano frágil: Una actualización. Revista Espanola de Geriatria y Gerontologia. 2015;50:74-81.

21. Radaelli R, Wilhelm EN, Botton CE, Rech A, Bottaro M, Brown LE, et al. Effects of single vs. multiple-set short-term strength training in elderly women. Age. 2014;36:1-11.

22. Mitchell CJ, Oikawa SY, Ogborn DI, Nates NJ, MacNeil LG, Tarnopolsky M, et al. Daily chocolate milk consumption does not enhance the effect of resistance training in young and old men: A randomized controlled trial. Appl Physio/ Nutr Metab. 2014;40:199-202.

23. Villanueva MG, He J, Schroeder ET. Periodized resistance training with and without supplementation improve body composition and performance in older men. Eur $J$ Appl Physiol. 2014;114:891-905.

24. Liberati A, Altman DG, Tetzlaff J, Mulrow C, Gøtzsche PC, loannidis JPA, et al. The PRISMA statement for reporting systematic reviews and meta-analyses of studies that evaluate health care interventions: explanation and elaboration. PLoS Med. 2009. 6:e1000100.

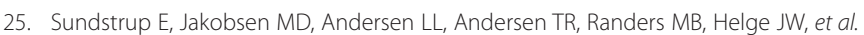
Positive effects of 1-year football and strength training on mechanical muscle function and functional capacity in elderly men. Eur J Appl Physiol. 2016;116:1127-38.

26. Zdzieblik D, Oesser S, Baumstark MW, Gollhofer A, König D. Collagen peptide supplementation in combination with resistance training improves body composition and increases muscle strength in elderly sarcopenic men: A randomised controlled trial. Br J Nutr. 2015;114:1237-45.

27. Batista A, Monteiro CP, Borrego R, Matias CN, Teixeira FJ, Valamatos MJ, et al. Association between whey protein, regional fat mass, and strength in resistance-trained men: $\mathrm{A}$ cross-sectional study. Appl Physiol Nutr Metab. 2019;44:7-12.

28. Beurskens R, Gollhofer A, Muehlbauer T, Cardinale M, Granacher U. Effects of heavyresistance strength and balance training on unilateral and bilateral leg strength performance in old adults. PLoS One. 2015;10.

29. Andersen TR, Schmidt JF, Nielsen JJ, Randers MB, Sundstrup E, Jakobsen MD, et al. Effect of football or strength training on functional ability and physical performance in untrained old men. Scand J Med Sci Sport. 2014;24:76-85.

30. Fernández-Lezaun E, Schumann M, Mäkinen T, Kyröläinen $H$, Walker S. Effects of resistance training frequency on cardiorespiratory fitness in older men and women during intervention and follow-up. Exp Gerontol. 2017;95:44-53.

31. Schmidt JF, Hansen PR, Andersen TR, Andersen LJ, Hornstrup T, Krustrup P, et al. Cardiovascular adaptations to 4 and 12 months of football or strength training in 65- to 75-year-old untrained men. Scand J Med Sci Sport. 2014;24:86-97. 